\title{
Efektifitas Model Problem Based Learning dan Model Group Investigation dalam Meningkatkan Karakter Anti Korupsi
}

\author{
Nika F Trisnawati ${ }^{*}$ dan Sundari Sundari ${ }^{2}$ \\ 1*2Program Studi Pendidikan Matematika, Universitas Muhammadiyah Sorong \\ Jalan Pendidikan KM 8, Kota Sorong, Papua Barat, Indonesia \\ 1*nfetristrisnawati@gmail.com, 2ndarisundari212@gmail.com
}

Artikel diterima: 27-11-2019, direvisi: 28-05-2020, diterbitkan: 31-05-2020

\begin{abstract}
Abstrak
Pendidikan anti korupsi merupakan salah satu cara mencegah perilaku korupsi sejak dini, kesuksesan dalam membangun karakter mahasiswa merupakan salah satu indikator kesuksesan dalam membangun Negara. Tujuan penelitian untuk mengetahui keefektifan peningkatan karakter anti korupsi pada proses pembelajaran dengan melakukan penerapan model Problem Based Learning (PBL) dan Group Investigation (GI), kemudian dibandingkan antara keefektifan pembelajaran PBL dan GI terhadap peningkatan karakter anti korupsi. Merupakan penelitian Quasi Experiment dengan Non-Equivalent Pretest-Posttest Design. Populasi penelitian adalah seluruh mahasiswa semester VI Pendidikan Matematika Universitas Muhammadiyah Sorong dengan dua kelas sebagai sampel acak. Hasil penelitian menunjukkan bahwa pembelajaran matematika menggunakan PBL maupun Gl efektif meningkatkan karakter anti korupsi mahasiswa, dan berdasarkan uji $T^{2}$ Hotelling's menyatakan bahwa tidak ada perbedaan antara keduanya. Penelitian ini sangat berguna untuk mengetahui modelmodel pembelajaran yang efektif dalam menerapkan pendidikan karakter dalam perkuliahan di kelas.

Kata kunci: Efektifitas, Group Investigation, GI, Karakter Anti Korupsi, Problem Based Learning, PBL, Quasi Experiment.

\section{Effectiveness of Problem Based Learning Models and Group Investigation Models in Improving Anti-Corruption Character}

Abstract

Anti-corruption education is one way to prevent corrupt behavior from an early age, success in building student character is one indicator of success in developing the country. The research objective is to determine the effectiveness of increasing anti-corruption character in the learning process by applying the Problem Based Learning (PBL) and Group Investigation (GI) models, then comparing the effectiveness of PBL and Gl learning towards improving anticorruption character. This is a Quasi-Experimental study with Non-Equivalent Pretest-Posttest Design. The study population was all sixth-semester students of Mathematics Education at the University of Muhammadiyah Sorong with two classes as a random sample. The results showed that mathematics learning using PBL and GI was effective in enhancing students' anticorruption character, and based on the Hotteling's $T 2$ test stated that there was no difference between the two. This research is very useful to find out effective learning models in implementing character education in lectures in class.

Keywords: Effectiveness, Group Investigation, GI, Anti-Corruption Character, Problem Based Learning, PBL, Quasi Experiment.
\end{abstract}




\section{Pendahuluan}

Indonesia hari ini ditandai dengan krisis multidimensi yang antara lain tercermin dalam perilaku masyarakat yang menjadi lebih korup, masyarakat awam yang lebih rapuh dan menjadi kehilangan arah, menunjukkan sikap anti sosial, tanpa orientasi dan mudah goyah, beringas, anti kemapanan, dan kehilangan keseimbangan antara rasio dan emosinya (Maryati \& Priatna, 2017).

Generasi penerus bangsa harus diberi didikan untuk bersedia bekerja keras dengan menjalani proses dan meninggalkan budaya instan serta mencoba menyibukkan diri dengan berbagai usaha untuk menangkis budaya asing yang kurang sesuai dengan budaya bangsa. Salah satu cara yang dapat digunakan dengan sangat tepat untuk meningkatkan karakter anti korupsi adalah dengan mulai mengintegrasikannya pada pembelajaran di kelas, mulai dari TK hingga Perguruan Tinggi. Peguruan tinggi dalam konteks pendidikan formal menempati posisi di ujung akhir, menjadi problem solver pada kesempatan terakhir (the last opportunity) untuk menumbuhkan potensi karakter terpuji pada diri setiap individu sebagai generasi penerus bangsa. Membangun negeri akan sukses apabila sukses membangun karakter mahasiswa (Kemenristek Dikti, 2017). Dalam bukunya Mukodi dan Afid (2014) berpendapat bahwa pendidikan anti korupsi merupakan langkah pencegahan sejak dini terjadinya korupsi.
Guru harus mengajar dengan demokratis dan memberi ruang pada seluruh peserta didik untuk mencari dan bertanya sehingga dapat meminimalisir watak koruptif saat peserta didik dewasa. (Soyomukti, 2013).

Dunia perkuliahan adalah gerbang bagi mahasiswa dalam memasuki profesiprofesi yang dipilihnya. Dalam proses perkuliahannya, materi-materi yang diberikan adalah materi yang akan menjadi bekal mahasiswa dalam dunia profesi mereka nantinya, sehingga dirasa sangat penting dalam mengajarkan sikap anti korupsi ini pada kalangan mahasiswa, sehingga saat mereka lulus dan memasuki dunia kerja bukan hanya ilmu tetapi telah siap dengan mental dan karakter yang anti korupsi, sehingga dengan diterapkannya pendidikan anti korupsi pada mahasiswa diharapkan generasi muda bangsa Indonesia akan lebih tangguh dan bijak dalam melawan korupsi yang ada disekitarnya. Pembentukan karakter anti korupsi diharapkan dapat menjadi salah satu upaya untuk menyelamatkan pemuda penerus bangsa agar kedepannya tidak menjadi penerus tindakan korupsi generasi sebelumnya.

Dalam laporan tahunan KPK tahun 2016, terdapat 9 propinsi yang menjadi sasaran pelaksanaan korsupgah terintegrasi, salah satunya adalah Propinsi Papua Barat yang mendapatkan dana anggaran otonomi khusus yang cukup besar, sehingga berdasarkan hal tersebut 
dirasa perlu untuk diadakan pendampingan. Dengan alasan tersebut, maka sangat perlu dimulai penanaman karakter anti korupsi sedini mungkin. Salah satu caranya yaitu dengan pengintegrasian karakter anti korupsi pada setiap mata kuliah di kampus, salah satunya yaitu dengan menerapkan metode pembelajaran yang dapat digunakan untuk mengintegrasikan nilai-nilai karakter anti korupsi di kelas.

Terdapat sembilan karakter yang sangat penting untuk dimiliki oleh setiap individu, yaitu: (a) inti (jujur, disiplin, dan tanggung jawab), (b) sikap (adil, berani, dan peduli), serta (c) etos kerja (kerja keras, sederhana, dan mandiri). (Justiana, dkk, 2014; Handoyo, 2013).

Karakter inti adalah nilai dasar dari karakter anti korupsi yang menjadi nilai utama dan harus ditanamkan pada setiap diri seseorang agar dapat dibentuk nilainilai anti korupsi lainnya. Penelitian ini berfokus mengukur adanya perubahan karakter inti pada diri peserta didik yaitu jujur, disiplin dan tanggung jawab. Indikator untuk mengukur nilai kejujuran adalah tidak menyontek, dapat mengungkapkan pendapat/ mengambil sikap pada masalah yang diberikan dengan benar. Indikator untuk nilai kedisiplinan adalah mengikuti jadwal perkuliahan dan melaksanakan proses perkuliahan sesuai peraturan pembelajaran. Sedangkan indikator yang dipergunakan untuk mengukur nilai tanggung jawab peserta didik adalah mengerjakan tugas dengan baik.

Internalisasi pendidikan anti korupsi dalam pembelajaran dapat dilakukan dengan menerapkan beberapa model, metode ataupun pendekatan pembelajaran yang tepat menurut pandangan konstruksivisme, diantaranya yaitu metode Reasoning and problem solving, metode inquiri Training, Model Problem Based Instruction/ Problem Based Learning, Model Konseptual, Model Investigation, pendekatan Scaffolding. (Mukodi \& Afid Burhanuddin, 2014; Damayanti \& Afriansyah, 2018; Handoko \& Winarno, 2019).

Dari penelitian yang telah dilakukan oleh Utari (2016) diketahui bahwa proses pembelajaran menggunakan model PBL dengan melakukan penilaian sikap disiplin, jujur dan penilaian hasil belajar secara kognitif menunjukkan peningkatan dari siklus I ke Siklus II.

Kemudian, menurut Sudiarta, dkk. (2014) nilai karakter siswa setelah diterapkan model pembelajaran GI meningkat secara signifikan dari pertemuan pertama sampai ke-empat berturut-turut 2,53, 2,99, 3,42 dan 4,13 dengan kategori Mulai Berkembang (MB).

Berdasarkan beberapa hasil penelitian tersebut, maka peneliti ingin melihat keefektifan dari model pembelajaran Problem Based Learning (PBL) dan Model Group Investigation (GI) terhadap peningkatan karakter anti korupsi yang dilihat dari indikator untuk karakter inti, 
yaitu disiplin, jujuran, dan tanggung jawab.

Oleh karenanya penulis melaksanakan penelitian yang berjudul "Efektifitas Model Problem Based Learning dan Model Group Investigation dalam Meningkatkan Karakter Anti Korupsi pada Mata Kuliah Analisis Real 2 di Universitas Muhammadiyah Sorong."

\section{Metode}

Penelitian ini menjadikan seluruh mahasiswa semester VI Pendidikan Matematika FKIP UM Sorong tahun pelajaran 2018/2019 sebagai populasi, sedangkan sampel dalam penelitian ini adalah kelas $E$ dan kelas $F$ Pendidikan Matematika FKIP UM Sorong dengan dua kelas sebagai sampel acak, sehingga dipilih kelas E untuk Eksperimen PBL yang terdiri atas 25 mahasiswa, sedangkan eksperimen $\mathrm{Gl}$ diberlakukan di kelas $\mathrm{F}$ dengan jumlah mahasiswa 25 orang. Desain dari penelitian ini adalah pretestposttest non-equivalent group design dimana penelitian ini merupakan eksperimen semu (Faturohman \& Afriansyah, 2020). Proses pengumpulan data dalam penelitian ini yaitu dimulai dengan cara memberikan angket karakter anti korupsi pada mahasiswa sebelum diberikan perlakuan yang berguna untuk memperoleh data sebelum perlakuan. Selanjutnya penelitian dilakukan dengan mulai melakukan pembelajaran menggunakan PBL untuk kelas $E$ dan model GI untuk kelas F. Serta memberikan posttest berupa angket karakter anti korupsi mahasiswa untuk mengetahui ada tidaknya perubahan karakter anti korupsi setelah diberikannya kedua model pada masing-masing kelas.

Perangkat yang akan dipergunakan untuk penelitian ini telah melalui proses validasi terlebih dahulu. Hasil dari uji validasi oleh dua orang ahli menyatakan seluruh perangkat valid dan dapat digunakan, hasil untuk masing-masing perangkat yaitu; lembar Observasi Dosen $(3,6)$, lembar observasi mahasiswa $(3,7)$, Angket Respon Mahasiswa (3,3), Angket Karakter anti korupsi $(3,3)$, Tes Hasil Belajar $(4,5), \operatorname{RPP}(4,3), \operatorname{LKS}(4,5)$ dan Modul $(4,4)$ maka dapat diinterpretasikan bahwa hasil rata-rata validasi seluruh perangkat penelitian 3,95 yang berada pada kategori Valid. Sehingga perangkat penelitian ini layak untuk dipergunakan dalam melaksanakan proses penelitian.

Data hasil penelitian kemudian akan dianalisis dengan dua cara, yaitu analisis secara deskriptif dan analisis secara inferensial. Analisis secara deskriptif dipergunakan untuk memberikan deskripsi tentang kondisi sebelum dilakukan perlakuan dan setelah dilakukan perlakuan dari dua kelas yang menjadi sampel penelitian. Kemudian analisis secara inferensial digunakan sebagai dasar dalam pengambilan kesimpulan penelitian yaitu dengan cara melakukan uji keefektifan serta uji perbandingan keefektifan dari penerapan model pembelajaran. 
Salah satu cara melakukan analisis keefektifan model pembelajaran yaitu dapat dilihat berdasarkan pada kriteria pencapaian dari tujuan pembelajaran tersebut. Model pembelajaran PBL maupun GI dikatakan efektif meningkatkan karakter anti korupsi apabila rata-rata nilai gain dari angket karakter anti korupsi mahasiswa setelah penerapan Model PBL atau GI lebih dari 0,29 dengan rata-rata angket karakter anti korupsi mahasiswa dengan kategorisasi sedang, yaitu lebih dari 2,49 dan hasil observasi karakter anti korupsi mahasiswa dengan nilai inti yaitu disiplin, jujuran, dan tanggung jawab berada pada kategori baik. Sedangkan untuk mengetahui perbedaan keefektifan dari model PBL dan GI setelah dilakukan uji multivariat $T^{2}$ Hotelling's. Dikatakan terdapat perbedaan apabila hasil signifikansi < 0,05. Uji Asumsi harus dilaksanakan terlebih dahulu dan memenuhi syarat untuk melakukan analisis data lebih lanjut. Uji asumsi yang wajib dipenuhi yaitu berupa uji normalitas dengan Kriteria keputusan $\mathrm{H}_{0}$ ditolak jika $d^{2} \leq X^{2}(p ; \alpha)$ yang kurang dari $50 \%$ dari data yang diamati (Johnson \& Christensen, 2014) dan uji homogenitas dengan kriteria dari nilai signifikansi yang dihasilkan adalah lebih dari 0,05 yang berarti matriks kovarians dari kedua kelas adalah homogen.

Selanjutnya akan dilakukan analisis data dengan one sample t-test guna mengetahui efektifitas dari pembelajaran dengan model PBL dan Model GI dalam meningkatkan karakter anti korupsi. Sementara itu, analisis perbedaan keefektifan dalam meningkatkan karakter anti korupsi antara pembelajaran dengan $\mathrm{PBL}$ dan $\mathrm{Gl}$ dihitung menggunakan pengujian Multivariate Analysis of Variance (MANOVA) $\mathrm{T}^{2}$ Hotelling's dengan taraf signifikansi untuk pengujian keefektifan maupun uji perbandingan ialah 0,05. Selanjutnya apabila terdapat perbedaan nilai signifikan, maka akan dilaksanakan pengujian lanjutan berupa uji univariat guna melihat apakah ada variabel tertentu yang memiliki kontribusi terhadap adanya perbedaan antara kedua model yang diteliti dan jika diperoleh hasil yang menunjukkan bahwa tidak terdapat perbedaan, maka pengujian tidak dilanjutkan.

\section{Hasil dan Pembahasan}

\section{A. Hasil}

Hasil keterlaksanaan pembelajaran pada masing-masing model dapat dilihat pada Tabel 1 berikut.

Tabel 1.

Data Keterlaksanaan Pembelajaran dengan Model PBL dan GI

\begin{tabular}{ccccccc}
\hline $\begin{array}{c}\text { Perte- } \\
\text { muan }\end{array}$ & I & II & III & IV & $\begin{array}{c}\text { Rata- } \\
\text { Rata }\end{array}$ & $\begin{array}{c}\text { Kate- } \\
\text { gori }\end{array}$ \\
\hline PBL & 3.67 & 3.74 & 3.83 & 4 & 3.81 & $\begin{array}{c}\text { Sangat } \\
\text { Baik }\end{array}$ \\
\hline GI & 3.58 & 3.69 & 3.93 & 3.98 & 3.80 & $\begin{array}{c}\text { Sangat } \\
\text { Baik }\end{array}$ \\
\hline
\end{tabular}

Dari Tabel 1 terlihat bahwa dalam menerapkan perlakuan pada masingmasing kelas eksperimen, baik dengan model PBL maupun Gl terlaksana dengan sangat baik. Mahasiswa tidak mengalami 
kesulitan untuk mengikuti pembelajaran dengan model tersebut. Mahasiswa mengikuti pembelajaran pada masingmasing model dengan baik, dan memperlihatkan peningkatan karakter anti korupsi dari aktivitas yang diobservasi. Hal tersebut terlihat pada Tabel 2 berikut ini.

Tabel 2.

Hasil Observasi Sikap Karakter Anti Korupsi Mahasiswa

\begin{tabular}{ccccccc}
\hline \multirow{2}{*}{ Model } & \multicolumn{6}{c}{ Rata-rata hasil dari Aspek yang Diamati } \\
\cline { 2 - 7 } & 1 & 2 & 3 & 4 & 5 & 6 \\
\hline PBL & 3 & 3,75 & 3 & 3 & 3,75 & 3,75 \\
\hline GI & 3,19 & 3,37 & 3,13 & 2,94 & 3,69 & 3,00
\end{tabular}

Ke-enam aspek yang diobservasi mewakili karakter inti dari pembelajaran anti korupsi, yaitu jujur, bertanggung jawab dan disiplin. Rata-rata dari empat pertemuan pada masing masing aspek diperoleh dengan kategori baik. Hal ini dapat diinterpretasikan bahwa pada saat kegiatan pembelajaran mahasiswa mengalami peningkatan sikap karakter anti korupsi yang ditunjukkan dalam setiap pertemuan. Selain dari segi sikap pada setiap pertemuan, penanaman karakter anti korupsi ini juga dilihat dengan menggunakan angket karakter anti korupsi yang bagikan sebagai pre test dan post test, yang bertujuan untuk mengetahui ada tidaknya peningkatan karakter anti korupsi dari mahasiswa sebelum dan setelah diberikannya perlakuan. Berikut hasil rekapitulasi rata-rata hasil angket karakter anti korupsi pada Tabel 3.

Tabel 3.
Data Hasil Rata-rata Pre test dan Post test Angket Karakter Anti Korupsi Mahasiswa

\begin{tabular}{cccccc|}
\hline \multirow{2}{*}{ Model Sampel } & \multicolumn{4}{c}{ Rata-Rata } \\
\cline { 2 - 6 } & & $\begin{array}{c}\text { Pre } \\
\text { Test }\end{array}$ & Kategori & $\begin{array}{c}\text { Post } \\
\text { Test }\end{array}$ & Kategori \\
\hline PBL & 25 & 2,25 & cukup & 3,4 & baik \\
\hline GI & 25 & 2,4 & cukup & 3,3 & baik
\end{tabular}

Tabel 3 menunjukkan bahwa kesadaran diri mahasiswa pada karakter anti korupsi pada diri mereka masing-masing mulai meningkat. Yang awalnya pada saat pre test hasil angket berada pada kategori cukup. Kemudian setelah dilakukan perlakuan selama 4 kali pertemuan dengan model PBL maupun GI, terlihat peningkatan hasil post test dari angket karakter anti korupsi pada diri mahasiswa yaitu berada pada kategori baik. Peningkatan ini dapat terlihat dari nilai gain yang diperoleh dari masing-masing model disajikan pada Tabel 4 berikut ini.

Tabel 4.

Hasil Rata-rata Perhitungan Gain Hasil Pre test Post test Angket Karakter Anti Korupsi

\begin{tabular}{cccc|}
\hline Model & Sampel & Rata-Rata & Kategori \\
\hline PBL & 25 & 0,51 & Sedang \\
\hline GI & 25 & 0,55 & Sedang \\
\hline
\end{tabular}

Rata-rata perhitungan nilai gain dari kedua skor angket karakter anti korupsi mahasiswa dengan model PBL adalah 0,51 dengan kategori sedang, dan dengan model Gl adalah 0,55 dengan kategori sedang. Hal ini berarti bahwa hipotesis peningkatan karakter anti korupsi pada kedua model terpenuhi yaitu keduanya lebih besar dari 0,29 diterima. 
Kemudian data hasil penelitian akan diuji keefektifan pembelajaran model PBL dan $\mathrm{GI}$ dengan menggunakan one sample t-test yang disajikan pada Tabel 5 .

Tabel 5.

Hasil Uji One Sample t-test Angket Karakter Anti Korupsi Mahasiswa

\begin{tabular}{cccc|}
\hline Aspek & Eksperimen & t & Sig. \\
\hline $\begin{array}{c}\text { Karakter Anti } \\
\text { Korupsi }\end{array}$ & PBL & 3,125 & 0,002 \\
\cline { 2 - 4 } & GI & 2,098 & 0,025 \\
\hline
\end{tabular}

Berdasarkan hasil one sample t-test pada tabel tersebut, nilai signifikansi dengan model PBL adalah 0,002 < 0,05 dan $\mathrm{Gl}$ dengan hasil nilai signifikansi 0,025 $<0,05$. Hal ini menunjukkan bahwa pembelajaran PBL maupun GI efektif meningkatkan karakter anti korupsi mahasiswa.

Setelah melakukan uji keefektifan, dilanjutkan dengan menguji perbedaan keefektifan antara pembelajaran dengan PBL dan GI menggunakan uji multivariate $T^{2}$ Hotelling dengan bantuan program SPSS 21.0 for windows. Hasil perhitungan tersebut menunjukkan bahwa taraf signifikansi yang diperoleh sebesar 0,393. Hal ini berarti bahwa taraf signifikansi yang diperoleh lebih dari 0,05. Sehingga, $H_{0}$ diterima dan dapat diinterpretasikan bahwa tidak terdapat perbedaan efektifitas secara signifikan antara kelas eksperimen 1 (Model PBL) dan kelas eksperimen 2 (Model GI). Karena hasil perhitungan tersebut menyatakan bahwa tidak terdapat perbedaan keefektifan, maka tidak diperlukan analisis dengan $t$ - univariat.

\section{B. Pembahasan}

Sangat perlu menanamkan karakter anti korupsi sedini mungkin pada masyarakat Papua Barat. Oleh karena itu perlunya pengintegrasian karakter anti korupsi dalam pembelajaran di Kampus, salah satunya dengan pemilihan metode pembelajaran yang tepat digunakan untuk internalisasi pendidikan karakter anti korupsi di kelas. Tidak semua model pembelajaran akan berpengaruh dan efektif untuk diterapkan pada kelas, materi, dan karakteristik siswa. Sehingga perlu dilakukan uji coba berupa eksperimen untuk mengetahui keefektifan suatu model pembelajaran terhadap peningkatan karakter anti korupsi.

Model pembelajaran berkelompok (kooperatif) merupakan model pembelajaran yang dapat menunjang peningkatan keaktifan dan partisipasi peserta didik dalam kelas (Afriansyah, 2015; Arsyad, 2016; Mulyono \& Arie Anang Setyo,2018; Setyo, 2017; Trisnawati, 2016; Trisnawati, 2017; Yunita, Alfi., dkk, 2020). Dengan meningkatnya partisipasi peserta didik dalam kelas diasumsikan bahwa tanggung jawab dan disiplin peserta didik akan menjadi baik, sehingga akan menimbulkan rasa percaya diri dan kejujuran dalam diri mereka terkait dengan kemampuan yang mereka miliki.

Dalam penelitian ini, model pembelajaran kooperatif yang digunakan pada proses perkuliahan yaitu model PBL dan GI pada mata kuliah Analisis Variabel 
Real pada materi Nilai Mutlak Bilangan Real dan Sifat Kelengkapan Bilangan Real. Penelitian ini dilakukan untuk mengetahui beberapa hal, yaitu keefektifan model PBL dalam meningkatkan karakter anti korupsi dan keefektifan model GI dalam meningkatkan karakter anti korupsi kemudian selanjutnya diantara dua kelas eksperimen dilihat ada tidaknya perbedaan keefektifan dalam meningkatkan karakter anti korupsi. Pada awal sebelum diberikan perlakuan, harus dipastikan terlebih dahulu kondisi kemampuan awal peserta didik pada dua kelas tersebut harus pada tingkatan yang sama. Setelah dilakukan analisis, hasilnya memperlihatkan bahwa kedua kelas memiliki kemampuan yang relatif sama, sehingga kelas-kelas tersebut layak diberikan perlakuan.

Setelah dilakukan pengujian secara statistik berupa one sample t-test, kelas dengan model pembelajaran PBL dan kelas dengan model pembelajaran GI efektif meningkatkan dan menumbuhkan karakter anti korupsi mahasiswa, hal ini dapat dilihat dari beberapa hal, yaitu keterlaksanaan pembelajaran yang sudah sesuai dengan rencana pembelajaran indikator keterlaksanaan pada kategori sangat baik $(3,81)$ untuk kelas PBL dan kategori sangat baik (3.80) untuk kelas GI. Dalam pembelajaran baik dengan model PBL maupun model GI mahasiswa tidak mengalami kesulitan untuk menyesuaikan diri dengan model pembelajaran yang digunakan. Mereka terlihat antusias dalam mengikuti perkuliahan dan menyelesaikan materi dan tugas yang diberikan dalam kelompok.

Mahasiswa menunjukkan adanya peningkatan karakter dalam pembelajaran baik di kelas E maupun di kelas F, hal ini berdasarkan data yang terdapat pada Tabel 2, rata-rata observasi sikap mahasiswa selama 4 kali pembelajaran berada pada kategori baik. Dari enam aspek yang diobservasi mewakili 3 karakter inti yaitu Jujur (aspek nomer 3 dan 4), disiplin (aspek nomer 1 dan 6) dan tanggung jawab (Aspek nomer 2 dan 5).

Beberapa hal yang terlihat dapat meningkatkan karakter dalam pembelajaran PBL yaitu mahasiswa dikelompokkan ke dalam kelompok heterogen yang ditentukan oleh Dosen, dalam pembelajaran berkelompok ini terlihat bahwa mahasiswa saling bekerja sama dan saling mengingatkan tanggung jawab mereka dalam kelompok. Hal ini senada dengan Cahyaningsih \& Ghufron (2016; Rinaldi \& Afriansyah, 2019) yang menyatakan bahwa pembelajaran dan pengajaran harus mampu membuat peserta didik menyelidiki masalah yang diberikan sehingga peserta didik dapat bertanggung jawab dalam tercapainya tujuan pembelajaran secara mandiri. Sehingga pada proses pembelajarannya menuntut mahasiswa agar dapat bertanggung jawab dalam menyelesaikan tugas dalam kelompoknya masing-masing. Pada pembelajaran PBL mahasiswa dituntut untuk dapat menyelesaikan 
permasalahan yang diberikan sendiri, sehingga waktu yang dibutuhkan oleh mahasiswa cukup lama, jika dalam pelaksanaannya terdapat anggota kelompok yang terlambat dan tidak disiplin dalam proses pengerjaannya, maka kelompok tersebut tidak dapat menyelesaikan tugas dan tanggung jawab kelompoknya, sebagaimana yang dikemukakan Anindyta dan Suwarjo (2014) PBL merupakan salah satu model pembelajaran yang inovatif yang menjadikan masalah sebagai acuan pembelajarannya sehingga proses pembelajaran berpusat pada siswa. Sehingga hal ini menuntut mahasiswa menjadi lebih disiplin terhadap pengerjaan dan waktu kedatangan.

Sedangkan hal-hal yang terlihat dapat meningkatkan karakter anti korupsi dalam pembelajaran dengan menggunakan model pembelajaran Gl yaitu pembelajaran Gl berpusat pada mahasiswa, dan juga dengan adanya proses investigasi serta dengan cara mencari sumber lain pada LKS menuntut kerjasama yang tinggi dalam kelompok yang menumbuhkan sikap tanggung jawab dan disiplin dalam proses investigasi, serta mahasiswa dituntut untuk menyiapkan hasil akhir sebagai laporan yang akan disampaikan di depan kelas yang menjadikan mahasiswa bersemangat untuk dapat menyelesaikan tugasnya tepat waktu sehingga mendorong mahasiswa dalam kelompok saling mengingatkan tanggung jawab agar tugas dapat terselesaikan dan dapat dipresentasikan di depan kelas sesuai dengan waktu dan tanggung jawab yang diberikan. Hal ini senada dengan hasil penelitian dari Retno, dkk (2014) yang menyatakan bahwa terdapat perbedaan efek terhadap karakter tanggung jawab sosial dalam implementasi pembelajaran dengan model GI modifikasi.

Lebih lanjut dapat terlihat dari perubahan pada lembar jawaban dan hasil akhir dari nilai pre test dan post test pada kedua kelas eksperimen. Pada lembar jawaban di pre test masih banyak terlihat hasil penyelesaian soal yang sama antara mahasiswa 1 dengan yang lain, walaupun jawaban tersebut salah. Hal ini menunjukkan mahasiswa belum jujur dan percaya diri dalam mengerjakan soal tersebut. Tetapi pada kegiatan post test mahasiswa terlihat lebih percaya diri untuk menyelesaikan soal dengan baik, hal ini dikarenakan mahasiswa memperoleh pemahaman yang baik dan disiplin serta tanggung jawab yang tinggi saat proses perkuliahan, sehingga mereka dapat menyelesaikan soal yang diberikan dengan penuh kejujuran. Hasil angket karakter anti korupsi pun menunjukkan peningkatan pemahaman akan sikap-sikap anti korupsi dari mahasiswa, hal ini terlihat dari perubahan hasil pre test dan post test angket karakter anti korupsi pada kelas eksperimen 1 dengan model PBL dari kategori cukup (2.25) menjadi berkategori baik $(3,4)$ dan pada kelas eksperimen 2 dengan model $\mathrm{Gl}$ dari 
kategori cukup $(2,4)$ menjadi kategori baik $(3,3)$.

Hasil pengujian hipotesis dari penelitian ini sesuai dengan kajian teori dan juga senada dengan penelitian dari Utari (2016) bahwa terlihat peningkatan dari penilaian sikap disiplin dan jujur pada diri siswa siswa dan hasil belajar siswa pada ranah kognitif setelah diterapkannya model PBL. Kemudian penelitian dari Sudiarta (2014) setelah diterapkan model pembelajaran Gl, terlihat adanya peningkatan rata-rata nilai karakter siswa dari pertemuan pertama sampai pertemuan ke-empat yaitu berturut-turut 2,53, menjadi 2,99, kemudian 3,42 dan terakhir 4,13 yang berarti menunjukkan kategori Mulai Berkembang (MB).

Perlu dilakukan pengujian guna mengetahui model pembelajaran yang lebih efektif. Untuk dapat mengetahui model mana yang lebih efektif meningkatkan karakter anti korupsi, maka dilakukan komparasi/perbandingan.

Analisis yang digunakan untuk membandingkan kedua model pembelajaran adalah analisis multivariate yaitu dengan MANOVA, dari hasil analisis diketahui bahwa antara dua model pembelajaran yang digunakan tidak ada perbedaan keefektifan dalam peningkatan karakter anti korupsi, sehingga tidak perlu melakukan uji lanjutan t-univariat yang digunakan untuk mengetahui variable-variabel tertentu yang mempengaruhi perbedaan secara keseluruhan.

\section{Penutup}

Kedua model ini dapat diterapkan dalam pembelajaran dengan mengintegrasikan nilai-nilai karakter anti korupsi di semua materi yang relefan dengan sintaks dan pencapaian tujuan pembelajaran dengan model PBL dan maupun model GI. Selanjutnya penelitian ini masih dapat dikembangkan lebih lanjut dengan mencari model-model pembelajaran lain yang dapat mengintegrasikan nilai-nilai karakter anti korupsi dalam pembelajaran di kelas.

\section{Daftar Pustaka}

Afriansyah, E. A. (2015). Qualitative Became Easier with ATLAS.ti. International Seminar on Mathematics, Science, and Computer Science Education MSCEIS 2015 Universitas Pendidikan Indonesia.

Anindyta, P., \& Suwarjo, S. (2014). Pengaruh Problem Based Learning terhadap Keterampilan Berpikir Kritis dan Regulasi Diri Siswa Kelas V. Jurnal Prima Edukasia, 2(2), 209-222.

Arsyad, R. B. (2016). Meningkatkan Hasil Belajar Matematika dengan Menggunakan Model Cooperative Learning dan teknik Napier pada siswa kelas IV B SD Muhammadiyah 2 Kota Sorong. Jurnal Qalam, 5(2), 14-25.

Cahyaningsih, U., \& Ghufron, A. (2016). Pengaruh Penggunaan Model Problem-Based Learning Terhadap Karakter Kreatif Dan Berpikir Kritis Dalam Pembelajaran Matematika. 
Jurnal Pendidikan Karakter, VI(1), 104115.

Damayanti, R., \& Afriansyah, E. A. (2018). Perbandingan Kemampuan Representasi Matematis Siswa antara Contextual Teaching and Learning dan Problem Based Learning. JIPM (Jurnal IImiah Pendidikan Matematika), 7(1), 30-39.

Faturohman, I., \& Afriansyah, E. A. (2020). Peningkatan Kemampuan Berpikir Kreatif Matematis Siswa melalui Creative Problem Solving. Mosharafa: Jurnal Pendidikan Matematika, 9(1), 107-118.

Handoyo, E. (2013). Pendidikan Antikorupsi. Yogyakarta: Penerbit Ombak.

Handoko, H. \& Winarno. (2019). Pengembangan Perangkat Pembelajaran Matematika melalui Pendekatan Scaffolding berbasis Karakter. Mosharafa: Jurnal Pendidikan Matematika, 8(3), 411422.

Johnson, B., \& Christensen, L. (2014). Education research Quantitative, qualitative, and mixed approaches ( $\left.3^{\text {rd }} E d\right)$. London: Sage.

Justiana, S., dkk. (2014). Buku Ajar Pendidikan dan Budaya Antikorupsi. Jakarta: Pusat Pendidikan dan Pelatihan Tenaga Kesehatan.

Majelis Pendidikan Dewan Pendidikan

Tinggi Kementrian Riset, Teknologi dan Pendidikan Tinggi. (2017). Memandang Revolusi Industri \&
Dialog Pendidikan Karakter di Perguruan Tinggi Indonesia. Jakarta: Direktorat Pembelajaran, Direktorat Jenderal Pembelajaran dan Kemahasiswaan Kementerian Riset, Teknologi, dan Pendidikan Tinggi.

Maryati, I., \& Priatna, N. (2017). Integrasi Nilai-Nilai Karakter Matematika Melalui Pembelajaran Kontekstual. Mosharafa: Jurnal Pendidikan Matematika, 6(3), 333-344.

Mukodi \& Burhanuddin, A. (2014). Pendidikan Anti Korupsi Rekonstruksi Intepretatif dan Aplikatif di Sekolah. Pacitan: LPPM Press STKIP PGRI Pacitan.

Mulyono, A. A. S. (2018). Komparasi Keefektifan Antara Model Pembelajaran Kooperatif Tipe NHT Dan Snowball Throwing Dalam Pembelajaran Geometri Analitik. Qalam: Jurnal IImu Kependidikan, 7(2), 115-123.

Retno, E. W., dkk (2014). Pengembangan Model Pembelajaran Group Investigation (GI) Berbantu Video Camtasia Pada Materi Peluang Untuk Siswa SMA/MA Negeri Kabupaten Cilacap Tahun Pelajaran 2013/2014. Jurnal Elektronik Pembelajaran Matematika, 2(5), 478-490.

Rinaldi, E., \& Afriansyah, E. A. (2019). Perbandingan

Kemampuan Pemecahan Masalah Matematis Siswa antara Problem Centered Learning dan Problem Based Learning. 
NUMERICAL: Jurnal Matematika dan

Pendidikan Matematika, 9-18.

Setyo, A. A. (2017). Keefektifan Pembelajaran Kooperatif Tipe STAD Integrasi Teori Belajar Van Hiele Pada Materi Geometri di Kelas V Sekolah Dasar. Qalam: Jurnal IImu Kependidikan, 6(1), 1-11.

Soyomukti, N. (2013). Teori-Teori Pendidikan dari Tradisional, (Neo) Liberal, Marxis- Sosialis, Hingga Postmodern. Yogyakarta: Ar-Ruzz Media.

Sudiarta, I P., dkk. (2014). Pengembangan Perangkat Pembelajaran Fisika SMP Bermuatan Karakter Dengan Setting Group Investigation. e-Journal Program Pascasarjana Universitas Pendidikan Ganesha Program Studi IPA, 4.

Tim Penyusun Laporan Tahunan KPK (2016). Laporan Tahunan KPK 2016. Jakarta: Komisi Pemberantasan Korupsi.

Trisnawati, N. F. (2016). Meningkatkan Hasil Belajar Matematika Siswa dengan menggunakan Model Pembelajaran Kooperatif Tipe ThinkPair-Share (TPS) pada Siswa Kelas VB SD Muhammadiyah I Kota Sorong. Qalam: Jurnal IImu Kependidikan, 5(2), 26-32.

Trisnawati, N. F. (2017). Efektivitas Model Pembelajaran Kooperatif Tipe Two Stay Two Stray dengan Pendekatan Saintifik dalam Pembelajaran Matematika pada Siswa SMP Negeri 2
Kota Sorong. Jurnal Median, IX(3), 3642.

Utari, L. N. (2016). Penerapan Model Pembelajaran PBL (Problem Based Learning) untuk Menumbuhkan Sikap Disiplin dan Sikap Jujur dalam Keterampilan Memecahkan Masalah pada Siswa. Institutional Repositories \& Scientific Journals.

Yunita, A., dkk. (2020). Pengaruh Penerapan Model Pembelajaran Kooperatif tipe teams games tournament terhadap hasil belajar matematika siswa. Mosharafa: Jurnal Pendidikan Matematika, 9(1), 23-33.

\section{Riwayat Hidup PENULIS}

\section{Nika Fetria Trisnawati, S. Pd., M. Pd.}

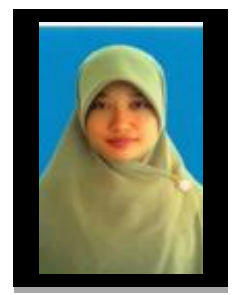

Lahir di Sorong, 13-02-1990. Dosen Tetap di FKIP Universitas Muhammadiyah Sorong. Studi S1 Pendidikan Matematika di Universitas Muhammadiyah Sorong, lulus tahun 2011; \& S2 Pendidikan Matematika di Universitas Negeri Makassar, lulus tahun 2016.

\section{Sundari, S. Pd., M. Pd.}

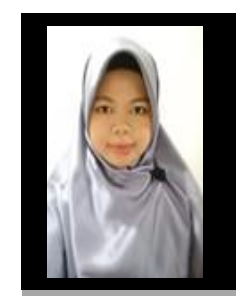
Lahir di Sorong, 29-08-1990. Dosen tetap di FKIP Universitas Muhammadiyah Sorong. Studi S1 Pendidikan Matematika di Universitas Muhammadiyah Sorong, lulus tahun 2012; \& S2 Pendidikan Matematika di Universitas Negeri Makassar, lulus tahun 2016. 